\title{
Ukryta strona fandomu — rzadkie i nienormatywne motywy seksualne w sztuce i literaturze fanowskiej
}

DOI: 10.19195/2083-7763.8.3

\section{Wprowadzenie}

Co najmniej od lat siedemdziesiątych XX wieku amatorska twórczość erotyczna jest obecna w fandomach medialnych ${ }^{1}$. Społeczności te, skupione wokół dzieł popkultury, takich jak seriale telewizyjne, filmy i książki, w ciągu kilku ostatnich dekad utrwaliły swoją pozycję prawdopodobnie największego źródła „oddolnej” twórczości erotycznej, a rozwój Internetu i technologii komputerowej nadał temu zjawisku prawdziwie masową skalę. Współcześnie możemy mówić o milionach tekstów, grafik czy animacji fanowskich, podejmujących na różne sposoby tematykę seksualną — od łagodnego romansu po twardą pornografię.

Podobnie jak w przypadku dostępnej w Internecie pornografii komercyjnej, $\mathrm{w}$ ramach tworzonej $\mathrm{w}$ fandomach erotyki powstało wiele nisz i gatunków. Wiele z nich wykorzystuje wątki seksualne skrajnie odbiegające od przedstawień akceptowanych w głównym nurcie popkultury, nieraz zaskakujące lub wręcz szokujące ze względu na swoją nietypowość. Wyraźnie dostrzegalne są też nurty erotyki fanowskiej skierowane do tradycyjnie rozumianych mniejszości seksualnych i często mocno związane $\mathrm{z}$ konstruowaniem gejowskiej lub lesbijskiej tożsamości ${ }^{2}$.

W pierwszej części niniejszego artykułu zostaną przedstawione różne przejawy tej różnorodności - poprzez identyfikację najpopularniejszych form erotyki fanowskiej i wykorzystywane w niej motywy. Zasadniczym celem będzie jednak zaproponowanie (przede wszystkim na podstawie dorobku teoretycznego fan

${ }^{1}$ C. Salmon, D. Symons, Slash fiction and human mating psychology, „The Journal of Sex Research" 41, 2004, nr 1, s. 94.

2 J. Brennan, 'Fandom is full of pearl clutching old ladies': Nonnies in the online slash closet, „International Journal of Cultural Studies” 17, 2014, s. 365. 
studies - interdyscyplinarnych studiów nad kulturą fanowską) kilku możliwych dróg wyjaśnienia faktu, że właśnie w społecznościach fanowskich amatorska erotyka rozwinęła się na skalę niespotykaną poza rynkiem komercyjnej pornografii, przyjmując tak rozmaite i nieraz skrajnie obsceniczne formy. W poszukiwaniach skupiono się przede wszystkim na dwóch aspektach współczesnych fandomów: wpływie przeniesienia się ich aktywności w środowisko społeczne Sieci oraz znaczeniu kultury fanowskiej, której już blisko półwieczna tradycja w znacznej mierze warunkuje to, jakie treści są dziś przez fanów tworzone i wypuszczane w obieg.

\section{Wokół powieści romansowej — od oper mydlanych po 50 twarzy Greya}

Erotyka fanowska praktycznie od początku swojego istnienia przyciągała uwagę wykorzystywaniem nietypowych lub zaskakujących motywów seksualnych. Slash, gatunek który de facto rozpoczął tradycję erotycznego pisarstwa fanowskiego i do dzisiaj pozostaje niezwykle popularny, opiera się na łączeniu heteroseksualnych postaci z dzieła źródłowego, najczęściej będących przyjaciółmi bądź rywalami, w homoseksualnych romansach. Ponadto, literatura ta najczęściej nie jest skierowania do gejów, lecz jest pisana przez heteroseksualne kobiety-fanki przeważnie dla kobiecych odbiorców. Takie połączenie motywów i grupy docelowej bywa szokujące nie tylko dla przeciętnego konsumenta popkultury, lecz także dla badaczy pierwszy raz podejmujących tę problematykę i to pomimo długiej historii samego zjawiska oraz sporej liczby opracowań naukowych, które wokół niego narosły ${ }^{3}$.

Jednak nie wszystkie nurty fanowskiej erotyki budzą kontrowersje tego typu. Szczególnie wśród fanek niezwykle popularna pozostaje literatura i inne formy twórczości wpisane w konwencję klasycznego, heteroseksualnego romansu (szczególnie tam, gdzie heteroseksualne wątki romantyczne są częścią lub nawet główną osią fabuły oryginału). W większości wypadków odtwarza ona najważniejsze konwencje gatunku powieści romantycznej, z budzącym podziw bohaterem i relatywnie pasywną bohaterką próbującą zdobyć jego serce ${ }^{4}$. Silny związek fandomu z fabułami romansowymi nie powinien dziwić - prawdopodobnie pierwszymi produkcjami telewizyjnymi, które zgromadziły wokół siebie znaczne grupy fanów, były opery mydlane czerpiące pełnymi garściami z omawianej konwencji. Tego typu seriale były też jednymi z pierwszych produkcji medialnych głównego nurtu,

${ }^{3}$ C. Salmon, D. Symons, op. cit., s. 95. Nadmierne wręcz zainteresowanie badaczy fanowskich tym gatunkiem, często połączone z ignorowaniem innych form fandomowej produkcji kulturowej, było opisywane przez wiodących autorów w obrębie fan studies, takich jak Matt Hills i Henry Jenkins, zob. M. Hills, Fan Cultures, Londyn 2002, s. 68-72; H. Jenkins, Fans, Bloggers and Gamers, Nowy Jork 2006, s. 9-36.

${ }^{4}$ C. Salomon, D. Symons, op. cit., s. 97. 
podejmujących otwarcie tematykę seksualną̧ ${ }^{5}$ Chociaż dzisiaj bez wątpienia nie są one siłą napędową ruchu fanowskiego, nie straciły całkowicie na znaczeniu ${ }^{6}$.

W praktyce romansowe fan fiction (literatura fanowska) stanowi dziś jeden z kluczowych nurtów twórczości fanowskiej. Na pierwszy rzut oka nieoczywistym, ale pod wieloma względami bardzo reprezentatywnym przykładem tego zjawiska, jest książka 50 twarzy Greya E.L. James - zdecydowanie największy sukces wydawniczy w historii fan fiction. Oryginalnie powieść fanowska na motywach serii „Zmierzch” (pod wieloma względami także klasycznego romansu, acz umieszczonego w konwencji fantastyki), po niewielkich modyfikacjach, w tym usunięciu bezpośrednich nawiązań do oryginału, została opublikowana jako samodzielne dzieło i zyskała olbrzymią, międzynarodową popularność ${ }^{7}$. Wzbudziła też wiele kontrowersji - ze względu zarówno na relatywnie odważne przedstawienie seksu, jak i zawarte w niej wątki BDSM.

Pomimo niewątpliwego wpływu na publiczne dyskusje o sadomasochizmie i szerzej - nienormatywnych praktykach seksualnych, w samej fabule książki trudno znaleźć pochwałę zachowań lub pragnień odbiegających wyraźnie od dominujących norm. Dewiacja seksualna tytułowego bohatera, Christiana Greya, stanowi przede wszystkim przeszkodę na drodze miłości głównych bohaterów, a jej źródłem jest traumatyczne dzieciństwo. W toku akcji trzech książek serii, przede wszystkim za sprawą miłości do głównej bohaterki, Anastazji, jego skłonności zostają przełamane, a para zawiera małżeństwo i włącza do swoich praktyk erotycznych jedynie drobne elementy sadomasochistycznej gry (w sposób, który trudno uznać za przekraczający normy społeczne). Taką interpretację wydają się potwierdzać także wrażenia czytelniczek zwracających uwagę raczej na zawartą w 50 twarzach... historię prawdziwej miłości, wygrywającej wbrew wszelkim przeciwnościom, niż opisy seksu. Czasem książki były wprost krytykowane przez szeregowych odbiorców za sztampowość romansowej fabuły ${ }^{8}$.

Tak jak zaprezentowany przykład, znaczna część twórczości fanowskiej raczej podąża za utrwalonymi konwencjami literackimi i wzorcami kulturowymi, nawet jeśli na pierwszy rzut oka sięga po elementy nietypowe lub kontrowersyjne. Nienormatywne praktyki seksualne czy nawiązania do seksualności mniejszości mogą być w takich dziełach zwykłym narzędziem fabularnym, nie podważając $\mathrm{w}$ istotny sposób dominujących norm czy patriarchalnych stosunków władzy, a pod pewnymi względami nawet je utrwalając - dysproporcja władzy i sprawczości jest trwale wpisana w formułę romansu i nie każda autorka fan fiction

5 S.E. Stern, A.D. Handel, Sexuality and mass media: The historical context of psychology's reaction to sexuality on the internet, „The Journal of Sex Research” 38, 2001, nr 4, s. 284.

6 Zob. N.K. Baym, Tune In, Log On: Soaps, Fandom, and Online Community, Londyn 2000.

7 J. Brennan, D. Large, 'Let's get a bit of context': "Fifty shades" and the phenomenon of 'pulling to publish' in “Twilight” fan fiction, „Media International Australia” 2014, nr 152, s. 28.

${ }^{8}$ R.A. Deller, C. Smith, Reading the BDSM romance: Reader responses to "Fifty Shades”, „Sexualities" 16, 2013, nr 8, s. 944. 
próbuje uciec od tych schematów. Ponadto, jak zostanie podkreślone w dalszej części, nawet na pierwszy rzut oka jeszcze bardziej nietypowe i transgresyjne formy twórczości fanowskiej niekoniecznie niosą z sobą wywrotowe przesłanie.

\section{Slash — najpopularniejszy nurt erotyki fanowskiej}

Wspomniany już slash w swojej oryginalnej odmianie (głównie literackiej i skierowanej do kobiet) stanowi nadal prawdopodobnie najpopularniejszą formę twórczości fanowskiej, obecną w większości dużych społeczności tego typu. Ukształtowana w latach siedemdziesiątych formuła wokół parowania Kirk/Spock, głównych męskich postaci serialu Star Trek, okazała się niezwykle żywotna i stabilna, pojawiając się w podobnej formie w coraz nowszych grupach fanowskich, a czasami wręcz dominując całą scenę pisarstwa opartego na konkretnym dziele (np. w niezwykle płodnym literacko fandomie Harry'ego Pottera).

Pierwotnie slash był często powiązany z ideami feministycznymi i stanowił manifestację autonomii seksualnej ze strony kobiet będących jego twórcami czy odbiorcami ${ }^{9}$. Współczesne badania sugerują jednak, że gatunek ten, mimo nieustannie zaskakującej formy, stracił sporo ze swojego wywrotowego charakteru. Wywiady pogłębione z czytelniczkami i pisarkami fanowskimi, przeprowadzone w 2008 roku przez CarrieLynn D. Reinhard, pokazują, że choć w ich narracjach można dostrzec elementy sprzeciwu wobec dominujących stosunków społecznych, slash służy im przede wszystkim jako forma eskapizmu i sposób na głębszy kontakt $\mathrm{z}$ ulubionymi dziełami popkultury ${ }^{10}$. Ta ostatnia motywacja jest przy tym jednym $z$ kluczowych elementów wszelkiej aktywności fanowskiej i dla rozmówczyń Reinhard wydawała się bardziej istotna niż dążenia emancypacyjne czy przełamywanie jakichkolwiek norm i wzorców kulturowych.

Do pewnego stopnia tezę o wywrotowym charakterze slashu podważa również praca Catherine Salmon i Don Symons Slash Fiction and Human Mating Psychology, mieszcząca się w paradygmacie psychologii ewolucyjnej. Ukazuje ona slash jako nieznaczną modyfikację tradycyjnej formuły powieści romantycznej, w taki sam sposób odwołującą się do kobiecych, ewolucyjnie ukształtowanych pragnień dotyczących sfery miłości i seksu ${ }^{11}$. W zasadzie jedynym elementem odróżniającym ten typ od romansu jest względna równorzędność partnerów męscy kochankowie mają zazwyczaj podobny status i umiejętności, nie tworząc

9 To ideologicznie uwikłanie slashu dobrze obrazują reakcje, jakie w latach osiemdziesiątych wywołały próby cenzury erotyki fanowskiej przez George’a Lucasa, twórcy serii Gwiezdne Wojny, opisane przez Henry’ego Jenkinsa. Znaczna część fanek krytykowała ten krok jako przejaw patriarchalnej dominacji i narzucania im represyjnej wizji kobiecej seksualności - H. Jenkins, Textual Poachers: Television Fans and Participatory Culture, Londyn 2012, s. 32.

10 C.D. Reinhard, If One Is Sexy, Two Is Even Sexier: Dialogue with Slashers on Identity and the Internet, Roksilde University 2009, s. 29-30.

11 C. Salmon, D. Symons, op. cit., s. 96. 
wyraźnego podziału na stronę aktywną i pasywną. W tej perspektywie miłość homoseksualna jest jedynie pretekstem do ukazania innej dynamiki w relacjach pomiędzy głównymi postaciami (co wydają się potwierdzać m.in. nierealistyczne przedstawienia seksu analnego, najczęściej unikanego przez autorki we własnym życiu erotycznym $)^{12}$.

Oczywiście samo zrównanie kochanków w fabule romansu nie jest neutralne i może być odczytywane jako forma emancypacji. Salmon i Symons wskazują, że znaczna część kobiet interesujących się slashem w młodości uchodziła za „chłopczyce”. Są to więc osoby skłonne do podejmowania tradycyjnie męskich ról społecznych; schemat powieści romantycznej, z charakterystycznymi dla niej (patriarchalnymi) wzorcami kobiecości, będzie dla nich mniej atrakcyjny ${ }^{13}$. Choć samo wyjaśnienie ewolucyjne może być dla socjologa mało przekonujące lub przynajmniej niepełne, argumenty autorów są trudne do odparcia. Wydaje się, że tworzony przez heteroseksualne kobiety slash, tak samo jak fanowskie romanse inkorporujące nietypowe praktyki seksualne, najczęściej nie mają charakteru silnie subwersywnego, a do pewnego stopnia mogą nawet utrwalać dominujące wzorce ról płciowych i seksualności.

\section{Erotyka fanowska LGBT}

Obok gatunków twórczości fanowskiej wpisującej się w utrwalone konwencje literackie lub nawet naśladującej formułę komercyjnej, heteroseksualnej pornografii istnieją nurty nie tylko odwołujące się do praktyk mniejszości seksualnych w sferze fabularnej, lecz ewidentnie zorientowane na fantazje i potrzeby osób do nich należących. Mająca długą historię literatura femslash (przekształcenie formuły slash, w której w romansie łączone są postaci kobiece) czy wywodzące się z Japonii komiksy i opowiadania yuri (romans młodych dziewcząt) są przykładem twórczości skierowanej przede wszystkim do homoseksualnych i biseksualnych kobiet ${ }^{14}$. Przedstawiając często heroiczne bohaterki i koncentrując się na kobiecej seksualności, mają one duży potencjał emancypacyjny — szczególnie że często są tworzone w kontrze do przedstawień seksu lesbijskiego, rozpowszechnionych w erotyce i pornografii głównego nurtu, przeznaczonych zasadniczo dla męskiego, heteroseksualnego odbiorcy.

Slash przedstawiający męskie, homoseksualne fabuły również może tworzyć inne znaczenia niż zasugerowane wcześniej w kontekście twórczości heteroseksualnych kobiet. Dobrym przykładem jest wykorzystanie tej formuły w gejowskim fandomie serialu Supernatural opisanym przez Josepha Brennana. Społeczność

12 Ibidem, s. 98.

13 Ibidem, s. 99.

14 A. Rogozińska, „Slash” i „Yaoi fan fiction” - internetowe społeczności fanów, „Rubikon. Kwartalnik Naukowy” 2004, nr 1-4, s. 209. 
zorganizowana jest wokół portalu LiveJournal i zorientowana przede wszystkim na graficzne odmiany slashu (szczególnie fotomontaże, łączące twarze głównych bohaterów serialu ze scenami z gejowskich filmów pornograficznych) ${ }^{15}$. Aktywność jej członków jest natomiast wyraźnie powiązana z kształtowaniem tożsamości gejowskiej, stanowiąc dla wielu z nich ważne miejsce wyrażania własnej seksualności, której nie mogą swobodnie okazywać w realnym świecie.

Jak wiadomo, kontekst społeczny jest kluczowy dla odbioru wszelkich tekstów kultury, a jego znaczenie bywa szczególnie łatwe do ukazania w przypadku erotyki i pornografii. Często nawet te same przedstawienia seksualności wpisane w inny kontekst, mogą być uznane albo za mieszczące się w normach społecznych, albo za pornograficzne (np. identyczne zdjęcie wystawione w galerii sztuki wywoła prawdopodobnie inne reakcje niż taki sam obraz zamieszczony w magazynie dla panów) ${ }^{16}$. Między innymi z tego względu wszelkie próby interpretacji erotyki fanowskiej na podstawie samej jej treści mają ograniczoną przydatność. Tworzenie sztuki i literatury tego typu jest działaniem w ramach wspólnoty, jaką stanowi konkretny fandom. Od dominujących w nim wartości i schematów interpretacyjnych $w$ dużej mierze będzie zależeć, jak rozumiana będzie fanowska erotyka - zarówno w relacji do dominujących w społeczeństwie wzorców, jak i seksualności samych jej twórców i odbiorców.

Podczas gdy w erotycznej twórczości heteroseksualnych fanów subwersja nie zawsze jest obecna, a nawet w przypadku pozornie wywrotowych gatunków straciła często pierwszoplanowe znaczenie, w przypadku fanów należących do środowisk LGBT wywrotowy charakter ich dzieł zdaje się znacznie trudniejszy do podważenia. Nie tylko zawierają one często skrajnie obsceniczne przedstawienia seksualności, lecz służą także zaspokojeniu potrzeb jednoznacznie odbiegających od populacyjnej normy. Brennan wskazuje jednak, że nie zawsze wiąże się to $\mathrm{z}$ ambicjami przekształcania społeczeństwa - wiele społeczności fanowskich opartych na erotyce w rzeczywistości jest relatywnie zamkniętych i chroni swoją aktywność przed niepożądanymi odbiorcami, przede wszystkim ze strachu przed negatywną oceną społeczeństwa ${ }^{17}$. To zagadnienie zostanie omówione w dalszej części artykułu.

\section{Inne mniejszościowe motywy seksualne — fetysze i transgresja}

Rozwój erotyki fanowskiej w Internecie sprawił, że zaczęła ona przyjmować bardziej różnorodne formy niż w erze przedinternetowej, wykorzystując $\mathrm{w}$ tym celu możliwości technologii cyfrowej i coraz szybszych łączy internetowych. Od lat

15 J. Brennan, op. cit., s. 364.

16 B.A. Eck, Nudity and framing: Classifying art, pornography, information, and ambiguity, „Sociological Forum” 16, 2001, nr 4, s. 604.

17 J. Brennan, op. cit., s. 373. 
dziewięćdziesiątych poprzedniego wieku do dominującego wcześniej fan fiction dołączyły masowo tworzone grafiki, animacje, filmy, a nawet gry komputerowe ${ }^{18}$. Wzrost różnorodności nie dotyczył jednak wyłącznie form ekspresji - twórczość fanowska zaczęła zapełniać nawet stosunkowo niewielkie i dla niewtajemniczonego odbiorcy dziwaczne nisze motywów seksualnych. Próba całościowego opisania tego zróżnicowania byłaby zarówno bezcelowa, jak i niemożliwa do zrealizowania w konwencji krótkiego tekstu naukowego. Warto jednak zwrócić uwagę na kilka wątków wykraczających poza opisaną już erotykę LGBT — obecność w ramach twórczości fanowskiej wątków fetyszystycznych i dzieł nastawionych na transgresję norm społecznych dotyczących seksualności.

Ogromna pula dostępnej w Internecie erotyki fanowskiej i jej zróżnicowanie sprawiają, że liczba możliwych do zidentyfikowania motywów seksualnych również może być przytłaczająca. Wiele z nich nie daje się też łatwo intepretować bez wglądu w motywację oraz sposób myślenia ich twórców i odbiorców. Dla przykładu, jak powinniśmy rozumieć powtarzające się w erotycznej literaturze na podstawie Harrýego Pottera wątki stosunków seksualnych pomiędzy człowiekiem i wilkołakiem albo człowiekiem i postacią magicznie przemienioną w zwierzę? Czy nasuwające się skojarzenie z zoofilią jest w jakikolwiek sposób trafne? Oczywiście, najlepszym rozwiązaniem tego problemu jest zazwyczaj dotarcie do autorów oraz czytelników tego typu dzieł i zebranie ich interpretacji. Uzyskanie informacji od fanów nie zawsze jest jednak proste i może zwyczajnie nie mieścić się z formule niektórych projektów badawczych. Czasem problemy może sprawiać nawet samo odróżnienie, co jest, a co nie jest erotyką. Wiele rodzajów pornografii fetyszystycznej obecnych $\mathrm{w}$ fandomach przyjmuje formy kompletnie niezrozumiałe dla niewtajemniczonego odbiorcy. Dla przykładu, typowe dla fetyszu makrofilii obrazy gigantek, w tym także motywy miażdżenia albo pożerania przez nie postaci normalnych rozmiarów, większości ludzi w ogóle nie będą kojarzyły się z seksem. Nie zmienia to faktu, że dla docelowych odbiorców stanowią źródło silnych doznań erotycznych ${ }^{19}$.

W odnajdywaniu i identyfikowaniu tego typu treści badacz nie musi polegać wyłącznie na własnej wiedzy czy intuicji. Niezwykle pomocne bywają kategoryzacje obecne na stronach fanowskich, przyjmujące często formę niezwykle rozbudowanych folksonomii — oddolnych systemów oznaczania treści, kształtowanych przez samych użytkowników serwisu (a wykorzystywanych m.in. przez strony

18 Tendencja ta dotyczy oczywiście także innych form erotyki i pornografii. Już dla prymitywnych komputerów domowych z lat osiemdziesiątych XX wieku powstawały pornograficzne programy i gry, mimo ich bardzo ograniczonych możliwości graficznych. Zasadniczą różnicą między pornografią głównego nurtu a fanowską jest to, że ta pierwsza dużo wcześniej przestała być zdominowana przez słowo pisane - zob. L. Nijakowski, Pornografia - historia, znaczenie, gatunki, Warszawa 2010, s. 218-232.

19 Macrophilia, [hasło w:] Wikipedia, the free encyclopedia, adres: https://en.wikipedia.org/ wiki/Macrophilia (dostęp: 8.01.2017). 
pornograficzne $)^{20}$. Używane przez fanów terminy nieraz wprost odsyłają do medycznych nazw różnego rodzaju fetyszyzmów i innych parafilii, jak np. popularne na kluczowej dla fandomu My Little Pony stronie Derpibooru oznaczenie „vore”, będące skrótem od worarefilii - fetyszu związanego z obrazami bycia pożeranym lub połykanym ${ }^{21}$. Wykorzystując te hasła, badacz może szybko dotrzeć do treści reprezentujących dany motyw, a często także do twórców i odbiorców nim zainteresowanych.

Innym cennym źródłem informacji są grupy tematyczne zorganizowane wokół bardzo wąskich nisz, na przykład wspomnianych obrazów makrofilskich (aktywna społeczność tego typu funkcjonuje na przykład w przywołanym środowisku My Little Pony, m.in. poprzez grupę tematyczną na stronie deviantART ${ }^{22}$ ). One również mogą umożliwić prosty dostęp do materiałów mieszczących się w danej konwencji i zainteresowanych nimi osób, a także tworzonych przez nie narracji. Trzeba przy tym zauważyć, że wykorzystanie wątków seksu w twórczości fanowskiej nie zawsze da się sprowadzić do odpowiedzi na konkretne potrzeby seksualne odbiorców - czasami wydaje się ona nastawiona przede wszystkim na łamanie dominujących norm i szokowanie.

Wokół wątków tego typu czasami tworzą się też grupy tematyczne, takie jak na przykład funkcjonująca na FiMFiction.net, stronie z literaturą fanowską My Little Pony, grupa RAPE, skupiona wokół fabuł gwałtu i przemocy seksualnej - jak sugeruje sama nazwa. O celowo odrzucającym charakterze tej społeczności świadczy nie tylko podejmowana w niej tematyka, lecz przede wszystkim ton opisów i komentarzy. Wita ona użytkowników napisem „Welcome! Welcome my fellow pony-rape enthusiasts!” („Witajcie! Witajcie entuzjaści gwałtu na kucykach!”), formułując $\mathrm{w}$ tym samym tonie na przykład definicje kategorii, na które dzielone są gromadzone przez grupę teksty ${ }^{23}$. Taka twórczość wydaje się wpisywać bardziej w tradycję obrazoburczych tekstów Markiza de Sade czy kina transgresyjnego lat siedemdziesiątych i osiemdziesiątych niż kanony erotyki i pornografii głównego nurtu. Treści tego typu funkcjonują na marginesach większości społeczności fanowskich, choć nie zawsze w sposób równie widoczny, jak w fandomie My Little Pony.

Zaprezentowany przekrój motywów i form ekspresji wykorzystywanych przez twórców erotyki fanowskiej nie jest bynajmniej wyczerpujący - pełny opis prawdopodobnie nie byłby w ogóle możliwy, jeśli wziąć pod uwagę skalę zjawiska i przemiany, jakim nieustannie one podlegają. Pozwala jednak wyobrazić sobie bogactwo wątków seksualnych obecnych we współczesnych fandomach. Dlaczego jednak właśnie te społeczności, skupione często wokół całkowicie pozbawionych

20 A. Mazières et al., Deep tags: toward a quantitative analysis of online pornography, „Porn Studies" 1,2014 , nr 1-2, s. 84.

21 Derpibooru - My Little Pony: Friendship is Magic Imageboard, https://derpibooru.org/tags/ vore (dostęp: 9.01.2017).

22 Giant-MLP, deviantART, http://giant-mlp.deviantart.com/ (dostęp: 9.01.2017).

${ }^{23}$ Rape, Fimfiction.net, https://www.fimfiction.net/group/197816/rape (dostęp: 9.01.2017). 
erotyki dzieł popkultury, stały się niejako centrum amatorskiej twórczości o tematyce seksualnej? Dalsza część tekstu zostanie poświęcona dwóm aspektom współczesnych społeczności fanowskich, które mogą przybliżyć nas do wyjaśnienia tego fenomenu - cechom fandomów jako społeczności internetowych i ich kulturowej specyfice sprzyjającej rozpowszechnianiu treści erotycznych.

\section{Znaczenie środowiska społecznego Sieci}

Rozwój Internetu zrewolucjonizował na wiele sposobów funkcjonowanie społeczności fanowskich, szczególnie zmieniając jednak techniczne możliwości tworzenia i rozpowszechniania sztuki oraz literatury. Trudno dostępne i kłopotliwe $\mathrm{w}$ produkcji czasopisma fanowskie (fanziny) zostały wyparte przez strony internetowe umożliwiające łatwe publikowanie własnych prac i dostęp do masowego odbiorcy ${ }^{24}$. Z kolei rozwój oprogramowania komputerowego umożliwił tworzenie grafiki, filmów czy nawet prostych gier przez osoby niemające profesjonalnej wiedzy, natomiast szerokopasmowe łącza dały możliwość swobodnego udostępniania nawet dużych, multimedialnych produkcji fanowskich tworzonych przy użyciu tych nowych narzędzi.

Jednak nie tylko sama łatwość komunikacji miała wpływ na rozkwit erotyki fanowskiej w ostatnich kilku dekadach; ogromne znaczenie ma także specyfika środowiska społecznego Sieci, a w szczególności związane z nim poczucie anonimowości i swoboda kształtowania własnego wizerunku. Użytkownicy Internetu nie tylko są w stanie sięgać po treści erotyczne i pornograficzne, nie obawiając się (w większości przypadków) zidentyfikowania, lecz mogą także na różne sposoby manipulować swoją tożsamością społecznąą ${ }^{25}$ W Sieci zniesione zostają bariery ograniczające interakcje społeczne w realnej przestrzeni (np. wygląd, status materialny, itp. $)^{26}$, co nie tylko czyni ją bardziej egalitarną, ale tworzy też możliwość działania kluczowego dla erotycznej aktywności w fandomach - odgrywania ról (ang. role-playing). Wykorzystywane przez fanów od bardzo wczesnego okresu istnienia Internetu MUD-y (ang. Multi-User Domain), wieloosobowe gry tekstowe, są doskonałym wyrazem tej swobody. Mając praktycznie nieograniczone możliwości manipulowania własnym wizerunkiem (w tym płcią, wiekiem itp.), uczestnicy takiej gry mogą tworzyć tożsamości i erotyczne interakcje odbiegające od tych dostępnych im w realnym świecie, realizując w tej sposób nawet najbardziej wyszukane fantazje.

Co więcej, sam rozmiar Globalnej Sieci i jej międzynarodowy charakter ułatwiają erotycznej twórczości fanów pozostawanie poza spojrzeniem większości

24 C. Salmon, D. Symons, op. cit., s. 94-100.

25 L. Nijakowski, op. cit., s. 223.

26 K. Barani, Rola więzi online w życiu społecznym człowieka, [w:] Psychologiczne konteksty Internetu, red. B. Szmigielska, Kraków 2009, s. 109. 
społeczeństwa oraz unikanie interwencji właścicieli praw autorskich ${ }^{27}$. Może temu sprzyjać szeroko rozpowszechniony stereotyp fana, kojarzący tego typu aktywność raczej z nieszkodliwym dziwactwem i przesadnym zaabsorbowaniem popkulturą niż produkcją amatorskiej erotyki ${ }^{28}$. Chociaż wielu ludzi dostrzega obecność pornograficznych przeróbek różnorakich dzieł popkultury, mało kto interpretuje je w kontekście aktywności fanowskiej. Sami twórcy tego typu erotyki często dbają, aby ich dzieła nie wpadły w niepowołane ręce, zamykając się w stosunkowo odizolowanych grupach (np. wymagających zaproszenia przez osobę będącą już członkiem). Wspominany fandom Supernatural stanowi skrajny przykład tej postawy. Jest on nie tylko oparty na całkowicie anonimowym uczestnictwie większości członków (bez użycia stałych nazw użytkownika itp.), lecz także zorientowany na jak najściślejsze ukrywanie swojej aktywności przed światem zewnętrznym. Świadczyła o tym chociażby paniczna reakcja wielu jego uczestników na fakt opublikowania przez popularnego artystę fanowskiego jednego ze swoich pornograficznych fotomontaży w komercyjnym czasopiśmie gejowskim. Wyjście z erotyką poza fandom i potencjalne zwrócenie na nią uwagi "niewtajemniczonych" odbiorców przez wielu zostało odebrane jako zagrożenie dla całej społeczności ${ }^{29}$.

Społeczność online dla części fanów stanowi zatem bezpieczne i komfortowe miejsce wyrażania seksualności na sposoby, które są nieosiągalne w rzeczywistości lub których okazanie wiązałoby się z drastycznymi sankcjami społecznymi. Samo to, połączone z ogromną liczbą ludzi zaangażowanych współcześnie w aktywność fanowską i jej oparciem na podatnych na przekształcenia tekstach popkultury, może wyjaśniać, dlaczego fandom jest dzisiaj tak przyjaznym środowiskiem dla amatorskich treści erotycznych, w tym prezentujących rzadkie lub nienormatywne praktyki. Aby jednak zrozumieć fenomen fanowskiej erotyki i pornografii, konieczne jest spojrzenie na kulturową specyfikę fandomów oraz tradycję, jaką wypracowały one przez ostatnie pół wieku.

\section{Znaczenie tradycji kulturowej fandomów}

Literatura naukowa dotycząca fandomów, chociaż stosunkowo rzadko poświęcająca szczególną uwagę problemowi erotyki, daje wiele wskazówek odnośnie do przyczyn jej powszechnej obecności w fandomach. Dotyczą one przede wszystkim kulturowej logiki aktywności fanów, opisywanej dziś najczęściej pod hasłami „kultury prosumpcji” (Siuda) lub „kultury uczestnictwa” (Jenkins). Przekształcanie dzieła źródłowego poprzez amatorską sztukę i literaturę ma w tym kontekście kluczowe znaczenie.

27 S.E. Stern, A.D. Handel, op. cit., s. 288.

28 H. Jenkins, op. cit., s. 10.

29 J. Brennan, op. cit., s. 373. 
Zasadnicza część aktywności fanów skupia się wokół kanonu - zbioru treści uważanych w danej społeczności za szczególnie ważne i prawomocne. W dzisiejszych czasach popularne dzieła popkultury najczęściej obrastają w różnego rodzaju poboczne produkty (gry komputerowe na podstawie filmów, książki rozwijające fabuły gier itp.), tworząc marki oparte na zasadzie interseksualności. Każde dodatkowe dzieło dodaje coś do fikcyjnego świata, wzbogacając go i wzmacniając rozumienie całości ${ }^{30}$. Fani znaczną część swojej energii poświęcają ocenie, selekcji i komentowaniu tych treści, często niosących dla nich szczególny ładunek emocjonalny. Sztuka i literatura fanowska stanowią jedną z najpowszechniejszych form interpretacji i rozwijania kanonu, odpowiadając na fantazje fanów i uzupełniając postrzegane przez nich braki oryginału ${ }^{31}$.

To, że często oczywistym brakiem są dla nich niedostatecznie rozbudowane wątki erotyczne, nie jest przypadkiem. Wiele dzieł cieszących się popularnością unika podejmowania wątków seksualnych, a w szczególności przedstawień seksu, ze względu na chęć dotarcia do określonych grup wiekowych. Państwowe instytucje oceniające filmy i inne produkcje medialne według ich zdatności dla niepełnoletnich widzów mają ogromną władzę, często decydując o finansowym powodzeniu konkretnego przedsięwzięcia ( $w$ skrajnych przypadkach np. nie dopuszczając do jego projekcji w większości kin). Wiele z nich, jak amerykańskie MPAA (Motion Picture Association of America), jest szczególnie wyczulonych na obecność erotyki. Pisarze i artyści fanowscy często wkraczają tam, gdzie twórcy oryginału nie chcieli lub nie mogli pokierować swojej pracy, dodając nowe wątki seksualne lub rozwijając te, które w dziele źródłowym były jedynie zaznaczone. Paradoksalnie, brak seksu w dziele źródłowym może być wręcz dodatkową zachętą, a nie przeszkodą dla tego typu twórczości - tam, gdzie wątki erotyczne zostały już dobrze rozwinięte, wyobraźnia fanów ma mniejszą rolę do odegrania.

Ponadto, erotyka wykorzystująca motywy i postaci, do których fani są mocno przywiązani, daje twórczości fanowskiej walory niedostępne dla wielu erotycznych i pornograficznych produkcji głównego nurtu. W przywoływanej pracy Reinhard respondentki wyraźnie wskazywały, że slash daje im możliwość głębszego kontaktu $\mathrm{z}$ ulubionymi bohaterami. Umożliwia im też poznawanie fantazji i interpretacji innych fanów, które mogą konfrontować $\mathrm{z}$ własnymi oraz przedyskutowywać $\mathrm{w}$ ramach grupy ${ }^{32}$. W przeprowadzonych przez autora niniejszego opracowania badaniach na temat społeczności My Little Pony wielu respondentów wskazywało na przewagę erotyki fanowskiej nad „normalną” pornografią - wykorzystanie lubianego przez nich fikcyjnego świata i osadzenie w głównych rolach ulubionych bohaterek serialu czyniło te treści ciekawszymi od oglądania seksu „anonimowych” aktorów.

30 P. Siuda, Mechanizmy kultury prosumpcji, czyli fani i ich globalne zróżnicowanie, „Studia Socjologiczne" 2012, nr 4, s. 118.

31 H. Jenkins, op. cit., s. 18.

32 C.D. Reinhard, op. cit., s. 13. 
Rozważając, dlaczego fandomy stały się przestrzenią szczególnie przyjazną dla erotyki, warto też zwrócić uwagę na pewne aspekty ich funkcjonowania rzadziej przywoływane w tym kontekście. Dla swobody twórczej fanów zasadnicze znaczenie miał zawsze ich niepewny status prawny. Wszelkie dzieła pochodne, choć nie całkiem pozbawione ochrony (np. na podstawie różnych form prawa dozwolonego użytku), są nieustannie narażone na interwencje i pozwy ze strony właścicieli praw autorskich ${ }^{33}$. Fani praktycznie od początku istnienia zjawiska musieli na różne sposoby adaptować się do tych zagrożeń, broniąc swojej autonomii i swobody twórczej przed koncernami medialnymi. Chociaż dzisiaj w coraz mniejszym stopniu aktywność fanowską interpretuje się w kategoriach oporu kulturowego czy „semiotycznej partyzantki” ${ }^{34}$, specyficzne interesy nadal lokują fanów przeważnie po stronie zwolenników wolności słowa i swobodnego dostępu do treści kultury. Wydaje się, że ma to odzwierciedlenie w polityce znacznej części stron publikujących fanowską literaturę i sztukę, stawiających użytkownikom bardzo niewielkie ograniczenia i broniących ich przed interwencjami zarówno ze strony aktorów zewnętrznych, jak i innych fanów, gdy konkretne treści wywołują kontrowersje.

Nie bez znaczenia jest też historyczny aspekt problemu, który przy okazji chyba najbardziej domaga się dokładniejszych badań i zazwyczaj jest przywoływany jedynie w sposób hasłowy. Pojawienie się konwencji slashu w latach siedemdziesiątych, na stosunkowo wczesnym etapie rozwoju społeczności fanowskich, a następnie jego replikowanie w większości nowo formujących się fandomów, nie pozostało obojętne dla swobody, z jaką inne formy erotyki mogły się tam rozwijać. Nawet w stosunkowo konserwatywnych społecznościach, takich jak na przykład polskojęzyczne fandomy, akceptacja fabuł opartych na romansach gejowskich nie pozostawia wielu argumentów za utrzymaniem innych form cenzury obyczajowej, ewentualnie poza tą dotyczącą treści budzących największy sprzeciw (np. opisów przemocy seksualnej) lub mogących wprost naruszać prawo (np. pornografia dziecięca, $\mathrm{w}$ wielu systemach prawnych zakazana nawet $\mathrm{w}$ formie wizerunku wytworzonego komputerowo lub tekstu). Polskie społeczności twórców fanowskich, jak na przykład popularne forum pisarskie Mirriel ${ }^{35}$, po początkowych oporach szybko przystosowały się do schematów obowiązujących w większości fandomów na Zachodzie - dużej swobody tworzenia i publikacji treści erotycznych przy jednoczesnym wyraźnym ich oznaczaniu i oddzielaniu od twórczości właściwej dla wszystkich odbiorców.

${ }^{33}$ Zob. S. Collins, Digital fair. Prosumption and the fair use defence, "Journal of Consumer Culture" 10, 2016, nr 1, s. 37-55.

${ }^{34}$ P. Siuda, Od dewiacji do głównego nurtu - ewolucja akademickiego spojrzenia na fanów, „Studia Medioznawcze” 2010, nr 1, s. 94.

35 Forum Literackie Mirriel, http://forum.mirriel.net (dostęp: 9.01.2017). 


\section{Podsumowanie}

Erotyka fanowska stanowi wciąż słabo rozpoznane przez badaczy społecznych zjawisko, w którym odbicie znajdują liczne przemiany i narracje typowe dla współczesnej seksualności mieszkańców Zachodu. Tak jak inne społeczności internetowe, fandomy stanowią często przestrzeń okazywania i realizacji pragnień oraz fantazji wykraczających daleko poza dominujące wyobrażenia o „normalnym" seksie, a nieraz wprost odrzucanych przez większość społeczeństwa i grożących stygmatyzacją każdemu, kto odważyłby się je wyrazić w realnym świecie. Ponadto, obecna w nich twórczość erotyczna wpisuje się doskonale w logikę ciągłej reinterpretacji i przetwarzania dzieła źródłowego, stanowiącą rdzeń współczesnej kultury fanowskiej. Ze względu na więź emocjonalną łączącą fanów z ich ulubionymi produkcjami medialnymi wykorzystywanie $\mathrm{w}$ erotyce motywów zaczerpniętych z tych dzieł czyni ją dla wielu potencjalnych odbiorców bardziej atrakcyjną niż komercyjne produkcje głównego nurtu. Długa tradycja nieoczywistej $\mathrm{w}$ formie, często pornograficznej twórczości i nieustanna walka fanów o utrzymanie własnej wolności twórczej w obliczu interwencji właścicieli praw autorskich dodatkowo wspomagają relatywnie przyjazny klimat dla podejmowania $\mathrm{w}$ fandomowej sztuce i pisarstwie tematyki seksualnej.

W kontekście opisanych charakterystyk nie powinna dziwić masowa obecność erotyki w społecznościach fanowskich. Jest ona jednak tylko powierzchnią dużo bardziej złożonego problemu. Badacze zainteresowani fandomami muszą poświęcić jeszcze wiele wysiłku, aby w pełni zrozumieć to niezwykle zróżnicowane i ciągle ewoluujące zjawisko. Mam nadzieję, że wyłożone podstawy dorobku fan studies $\mathrm{w}$ tej tematyce oraz zaproponowane tezy będą dla innych badaczy zachętą do głębszego zainteresowania się nią i podjęcia własnych badań. Współczesne fandomy stanowią prawdziwą skarbnicę wiedzy na temat ludzkiej seksualności i form, w jakich jest ona wyrażana w dzisiejszej rzeczywistości - wiedzą, z której stosunkowo niewielu korzysta, a od której oddziela nas często zaledwie kilka kliknięć myszy.

\section{Bibliografia}

Baym N.K., Tune In, Log On: Soaps, Fandom, and Online Community, Londyn 2000.

Brennan J., 'Fandom is full of pearl clutching old ladies': Nonnies in the online slash closet, „International Journal of Cultural Studies" 17, 2014, s. 363-380.

Brennan J., Large D., 'Let's get a bit of context': "Fifty shades" and the phenomenon of 'pulling to publish' in "Twilight” fan fiction, „Media International Australia” 2014, nr 152, s. 27-39.

Collins S., Digital fair. Prosumption and the fair use defence, „Journal of Consumer Culture” 10, 2016, nr 1, s. 37-55.

Deller R.A., Smith C., Reading the BDSM romance: Reader responses to „Fifty Shades”, „Sexualities” 16,2013 , nr 8, s. 932-950. 
Eck B.A., Nudity and framing: Classifying art, pornography, information, and ambiguity, „Sociological Forum" 16, 2001, nr 4, s. 603-632.

Hills M., Fan Cultures, Londyn 2002.

Jenkins H., Fans, Bloggers and Gamers, Nowy Jork 2006.

Jenkins H., Textual Poachers: Television Fans and Participatory Culture, Londyn 2012.

Mazières A. et al., Deep tags: toward a quantitative analysis of online pornography, „Porn Studies” 1, 2014, nr 1-2, s. 80-95.

Nijakowski L., Pornografia - historia, znaczenie, gatunki, Warszawa 2010.

Psychologiczne konteksty Internetu, red. B. Szmigielska, Kraków 2009.

Reinhard C.D., If One Is Sexy, Two Is Even Sexier: Dialogue with Slashers on Identity and the Internet, Roksilde University 2009.

Siuda P., Mechanizmy kultury prosumpcji, czyli fani i ich globalne zróżnicowanie, „Studia Socjologiczne" 2012, nr 4, s. 109-132.

Siuda P., Od dewiacji do głównego nurtu - ewolucja akademickiego spojrzenia na fanów, „Studia Medioznawcze" 2010, nr 1, s. 87-99.

Rogozińska A., „Slash” i „Yaoi fan fiction” - internetowe społeczności fanów, „Rubikon. Kwartalnik Naukowy" 2004, nr 1-4, s. 200-224.

Salmon C., Symons D., Slash fiction and human mating psychology, „The Journal of Sex Research” 41, 2004, nr 1, s. 94-100.

Stern S.E., Handel A.D., Sexuality and mass media: The historical context of psychology's reaction to sexuality on the internet, „The Journal of Sex Research” 38, 2001, nr 4, s. 283-291.

\section{The hidden side of the fandom — rare and nonnormative sexual themes in the fan-created art and literature}

\section{Summary}

For a few decades now amateur erotic art and literature is present on large scale in many fan communities, showing great diversity in forms of expression and subjects. Significant portion of them includes rare or nonnormative sexual themes. The goal of this article is to pinpoint main causes of this exceptional popularity of such themes in online fandom. Doing this, I will focus on two aspects of the problem: general characteristics of fandoms as internet communities and the specificity of the media fan culture, as it developed during half a decade of its existence. 